Article

\title{
Faith in the Ghosts of Literature. Poetic Hauntology in Derrida, Blanchot and Morrison's Beloved
}

\section{Elisabeth M. Loevlie}

Institute for Literature, Area Studies and European Literature, University of Oslo, PO Box 1003, Blindern, 0315 Oslo, Norway; E-Mail: e.m.lovlie@ilos.uio.no

Received: 15 May 2013; in revised form: 21 June 2013 / Accepted: 28 June 2013 /

Published: 4 July 2013

\begin{abstract}
Literature, this paper argues, is a privileged language that can give form to those specters of existence that resist the traditional ontological boundaries of being and non-being, alive and dead. This I describe as the "hauntology" of literature. Literature, unlike our everyday, referential language, is not obliged to refer to a determinable reality, or to sustain meaning. It can therefore be viewed as a negation of the world of things and sensible phenomena. Yet it gives us access to vivid and sensory rich worlds. The status of this literary world, then, is strangely in-between; its ontology is not present and fixed, but rather quivering or ghostlike. The "I" that speaks in a literary text never coincides with the "I" of the writing subject, rather they haunt each other. This theoretical understanding is based on texts by Jacques Derrida and Maurice Blanchot. The paper also draws an analogy between this spectral dynamic of literature and an understanding of religious faith or belief. Belief relates to that which cannot be ontologically fixed or verified, be it God, angels, or spirits. Literature, because it releases and sustains this ontological quivering, can transmit the ineffable, the repressed and transcendent. With this starting point, I turn to Toni Morrison's book Beloved (1987) and to Beloved's strange, spectral monologue. By giving literary voice to the dead, Morrison releases literature's hauntology to express the horror that history books cannot convey, and that our memory struggles to contain.
\end{abstract}

Keywords: hauntology; literature; referential suspension; Maurice Blanchot; Jacques Derrida; Morrison's Beloved 


\section{Introduction}

To live is to be haunted. Our "here and now", our material presence, is never stripped, bare or alone. Neither is our subjectivity. We are always caught up in invisible and intangible webs of the past, of the Other, of the future, of death. Our existence is therefore always in-between, defined of course by the materiality of our present being, but also by this immaterial flux that surrounds and situates us. Derrida's term hauntology, first coined in his Spectres of Marx in 1993, describes this instable or indefinable ontology. The term has proven itself a fruitful critical topos because it permits the discussion of a repeated, ungraspable roaming that colours our lives. ${ }^{1}$ Hauntology questions (or haunts!) its homophone concept ontology as it attempts to indicate that which moves insistently in-between being and non-being, existence and death. Hauntology therefore performs and releases what I shall describe as an ontological quivering.

It goes without saying that this haunting, despite its "success" in post-modern thought, is easily rejected and overlooked within the more dominating rationalist and secular discourses of our time. Reality is what you perceive, and hauntology is easily dismissed as merely one more French, fashionable and nonsensical term. However, our time is also one of revived religious activity, of a surging wave of so-called alternative lifestyles and remedies, and one look at popular culture reveals a plethora of vampires, ghosts, and other magical creatures with supernatural powers. ${ }^{2}$ Without going into details, all can be seen as symptomatic of a yearning to relate to those shades of existence that cannot be defined according to the traditional ontological criteria of being or non-being, alive or dead, material or immaterial. Existence offers a whole range of dimensions that don't fit this scheme. Rather they are in-between - ungraspable and unidentifiable. And while the dominating discourse, at least of the West, with its scientific, technological and economical base, expels these ghosts, a new desire to experience their mystery is apparent.

My aim in this paper is to explore literature as mode that invites and permits us to relate to and experience these haunting aspects of our human existence. I understand literature as a specific use of language through which the ineffable and unthinkable can, paradoxically, "speak". ${ }^{3}$ Here language strangely releases those spectres of life that other modes of discourse repress, exclude or simply fail to grasp. Literature moves us because it offers the unheard testimony of the unspeakable.

This understanding of literature will be developed with reference to Maurice Blanchot and Jacques Derrida. In a first part, however, I want to indicate the potential relevance of a larger theoretical framework, namely the so-called "religious turn" in continental thought. Especially interesting in this context are Derrida's thoughts on belief in God and atheism. What does it mean, one might ask, to believe in God or in heaven when these have no ontological founding? And how is this faith related to reading literature? These questions lead to an exploration of what I call the hauntology of literature. A

1 For a more in-depth treatment of Derrida and his notions of spectrality and hauntology, se for example Colin Davis, Haunted Subjects, Deconstruction, Psychoanalysis and the Return of the Dead [1] or Jodey Castricano, Cryptomimesis, The Gothic and Jacques Derrida's Ghost Writing [2].

2 Consider, for example, the sucess of the television series Vampire Diaries, based on L.J. Smith's bestselling books, or the film series The Twilight Saga based on Stephenie Meyer's books. Other exmples include the television series Supernatural or Buffy the Vampire Slayer, the Harry Potter stories and films, and the success of the Narnia films.

3 For more on this, see E.M. Loevlie, Literary Silences in Pascal, Rousseau and Beckett [3]. 
final section turns to Toni Morrison and her spectacular novel Beloved from 1987. Focusing on Beloved's monologues, I wish to show how this novel can be understood as exemplary of poetic language's ability to perform the unspeakable that is always haunting us.

\section{Derrida's Atheistic Faith}

In 1991 Derrida published the strangely autobiographical Circumfession (1993). The text appeared in Geoffrey Bennington's book Jacques Derrida. It is a series of reflections on his mother's imminent death and on St Augustin and his Confessions. Religion runs as a theme throughout, and it was here that his readers for the first time could read confessions like "my religion about which nobody understands anything” ([4], p. 154), or, referring to his mother, "she must have known that the constancy of God in my life is called by other names so that I quite rightly pass for an atheist” ([4], p. 155).

This publication and its religious undercurrent came as a surprise to most Derrida readers. One who was especially fascinated was John D. Caputo, who has since written extensively on Derrida and religion. He was particularly intrigued by the phrase quoted above: I rightly pass for an atheist. And in 2002, at a conference in Canada, Caputo asks Derrida what he means by this expression: "Why do you say that you rightly pass for an atheist instead of simply stating that I am an atheist? Is this because you have some doubts about whether you really are an atheist? Or because you have some doubts about the distinction beten atheism and belief in God?” ([5], p. 46) ${ }^{4}$. Derrida's answer fascinates. It is impossible, Derrida claims, to believe in God without passing through "a number of atheistic steps" (ibid.). True faith is always exposed to and accompanied by radical doubt and atheism: "True believers know they run the risk of being radical atheists” (ibid.). God, continues Derrida, is not an object alongside other objects. God has no essence, no presence, no substance. God, in other words, has no ontology. His being is irreducible to our categories of being or non-being. He is not. The question then becomes what it implies to believe in that which does not exist, which is beyond being, which is, if you like, supernatural? In order for belief to be authentic, Derrida continues (while underlining that this is a word he hardly ever uses), belief in God will be haunted by doubt and atheism. Any true believer must take into account God's ontological quivering and thereby expose itself to absolute doubt: "It is in the epoché, the suspension of belief, the suspension of the position of God as a thesis, that faith appears" (ibid.). To have faith is to devote oneself to a quivering on the verge of existence, a quivering that can never be finally confirmed, defined or circumscribed. Released from the confines of the real, from ontology, this spectral presence is called hauntology. Here the impossible being of non-being beckons.

Placing doubt as criteria for faith, Derrida refers back to the Christian mystics, who, he says, "experience the death of God, the disappearance of God, the nonexistence of God" (ibid.), but nonetheless keep praying. In our time, we might consider the testimony of Mother Theresa. The saint most of us recall for her deep devotion and life altering faith, displayed a new side in some recently published letters she wrote to her confessor, Rev. Michael Van Der Peet. In 1979 she wrote: “Jesus has a very special love for you. As for me, the silence and the emptiness are so great that I look and do not see, listen and do not hear" [6]. This silence is not, according to Derrida's line of thought, a mark of weak or diminished faith, but rather of a true, authentic belief in God. To believe is to have doubt, to experience what Pascal, in his Pensées, called "the eternal silence of these infinite spaces” ([7], p. 73).

\footnotetext{
4 The question and its answer can be heard on YouTube http://www.youtube.com/watch?v=hcl00tc-WHc.
} 
Derrida concludes his response to Caputo by claiming the impossibility of confirming boldly "I am a believer”, or "I am an atheist”. He dismisses such statements as absolutely ridiculous ([5], p. 47) because the conditions of faith and atheism are not congruent with such a strong identification. It is not, he says, a position one can be in. From our perspective, it is interesting that the hauntology of God seems to affect the ontology of the subject. In relation to an object that cannot be determined or fixed, the status of the subject, of my sense of being, is equally weakened. To believe in God is to experience a trembling of one's own ontology. Our question now is how these religious reflections might further inspire our understanding of what it is to be a faithful reader of literature.

\section{Literature and the Death of God}

The God Derrida invokes is better described in terms of absence than presence. It is not a God that can be fixed and placed in a transcendent beyond, but rather a God that repeatedly recedes from his omniscient place "up there". This goes hand in hand with Derrida's challenge to what he coins Western metaphysics, by which he means the dominating and ingrained dualistic system of thought that underlies our largely accepted description and ordering of life and the beyond. Within this system, God, (together with eternity, spirit, Truth, etc.) is placed and defined in opposition to our earthly life (time, flesh, immanence etc.). From this perspective, God is understood and conceptualized within a dualistic system of negatives.

It is of course this metaphysical God Nietzsche proclaimed dead-a death Derrida indirectly alludes to in the following phrase from Writing and Difference: "The death of God will ensure our salvation because the death of God alone can reawaken the divine” ([8], p. 184). The statement is paradoxical. How are we to understand the death of God as a prerequisite for renewed religious thought and experience? First of all, the God that must die is the metaphysical God locked in a dualistic, speculative system of thought. Metaphysics posits God at a reassuring distance from the physical, lived life. Within this dualistic, philosophical system of thought God is transcendent, beyond time and language. He is the origin, the true center, the totalizing meaning. But through this abstraction, God ultimately becomes irrelevant, inaccessible and uninteresting. Theorized into a higher principle of original truth, God becomes removed from the essence of our lives. This line of thinking, as Caputo often reminds us, is not new. It also constitutes the essence of Paul's message to the Corinthians, whose attempts to speculate God into an abstract principle caused them to lose sight of the living God (see for example [9], p. 1). Furthermore, it is this living God that Pascal celebrates in his famous "Mémorial”: “GOD of Abraham, GOD of Isaac, GOD of Jacob/not of philosophers and scholars" ([7], p. 178). And Søren Kierkegaard is another religious thinker who repeatedly rejected the God of the theologians of his time. Instead he turned to the God of fear and trembling, but also of love and devotion.

During the last 15-20 years post-structuralist critique has repeated this deathblow to the God of the philosophers, and as a result there has been a proliferation of new, challenging and I think important religious thought. It is possible yet again to think a God that matters, that stirs us up, and that is paradoxically accessible as a religious, transcendent experience in time and in language. God, it seems, is crossing lines. And it is exactly such crossing of lines that initiates the instable ontology that I am calling hauntology. The death of the metaphysical God clears an opening for the rebirth, or haunting, of a different God. 
But how then is this absent, dead and born-again God linked to literature? I would like to turn here to the French writer and thinker Maurice Blanchot, and his article "The Unnameable Beast”. Blanchot here reflects on literature and draws our attention to its original link to the sacred voice of the oracle. Referring to the Phaedrus he reminds us of Socrates' dismissal of writing - in which "someone speaks and yet no one is speaking” ([10], p. 36). This is a speech "that doesn't have behind it the personal guarantee of a real person" (ibid.). This dismissal goes hand in hand with another scepticism towards "another impersonal language", namely the oracle- “the pure speech that seeks to articulate the sacred. ... the voice of the oak or the stone” ([10], p. 37). There is, in other words, affinity between the sacred speech of the oracle and the potentially literary voice that emerges through what is written because none of them originate in the speaking subject. Blanchot continues:

Like sacred speech, what is written comes from no one knows where, it is authorless, without origin, and hence, refers to something more original. Behind the written word, no one is present, but it gives voice to absence, just as in the oracle where the divine speaks, the god himself is never present in his speech, and it is the absence of god that speaks then ([10], p. 38).

Writing, because it is severed from the original subject, testifies not to presence, but to absence. And Blanchot here suggests that this absence conditions its sacred potential. When no one is speaking, language is strangely free from the confines of the subject, and can thereby release and speak the impersonal, ineffable sacred. The Scripture can hence be compared to the oracle in that both allow the speaking of a God without presence, a God that is dead, or that is non-being. And returning to Derrida, we remember that this absent God is the one that inspires authentic faith. Writing performs and releases an ontological quivering, an instance of hauntology, and hence beckons us to faith, and to doubt.

\section{Mallarmé's Flower}

Let us turn now to Derrida's famous literary confession. He has a "taste (probably unconditional) for literature, more precisely for literary writing” ([11], p. 2). This preference is linked to literature’s radical independence from the subject. Unhinged from the interiority of a speaking person, this is a voice that can somehow bear testimony to the absence of an origin. ${ }^{5}$ But there is more. In the same manner that literature is free from its reference to any original subject, it is free from any obligation to communicate something about reality. What do I mean by this? Literature is not obliged to make sense, it is not obliged to be in referential harmony with the world "out there". As opposed to other modes of language (with the exception possibly of young children's language, articulated dreams or mad person's ramblings), there is no justified expectation that what is being said refers to something real. Therefore no one objects when literature describes a landscape with blue grass, red rivers and green skies. Literary speaking can also describe a specific house, in an existing street, but it is not obliged to be truthful in its description of this house.

This is what Blanchot describes as the prophetic dynamic of literature. This is a kind of language, he says, "that does not rely on something that already exists-neither on an already accepted truth nor on a language that has already been spoken or verified” ([10], p. 41). Literary speaking, like that of the

5 Of course this does not exclude or devalue more autobiographical or historical readings. Writing is of course also linked to its author, its period, its larger context. But it can never be finally reduced to these contextual elements. 
oracle, performs the reality it describes, it does not refer or describe something pre-existing, it is not held responsible for its relation to a common reality. Importantly it is also free in relation to previously verified or accepted forms of language. The language that we rely upon to make sense in our everyday lives is inscribed through at least a semblance of repetition without difference. When I therefore say "I am thirsty”, I can trust that others understand me and that my thirst can be quenched. But literature is not bound by this conformity of use, and can openly display language's inherent difference and deferral of meaning. It can hence reinvent our everyday language, invest it with different meanings and challenge its referentiality. As readers of literature, we are invited into this new, reinvented language that again permits a different experience of reality.

Derrida incorporates this performative aspect of literature into his definition of the "literary thing" in the short text "Literature in Secret": "every text given over to the public space, relatively legible or intelligible, but of which the content, the meaning, the reference, the signatory and the addressee are not fully determinable realities ... can become a literary thing” ([12], p. 7). The meaning of literature cannot be finally decided in reference to what we deem reality or context. ${ }^{6}$ This is literature's absolute freedom and non-obligation.

The description of the literary I am sketching here is of course largely indebted to Stéphane Mallarmé. Without going into detail, it is possible to consider his famous phrase in "Crisis in Poetry" from 1896: "I say: a flower! and outside the oblivion to which my voice relegates any shape, insofar as it is something other than the calyx, there arises musically, as the very idea and delicate, the one absent from every bouquet’' ([13], p. 76). Mallarmé describes poetic language as having the power to evoke a flower that is absent from any bouquet in the sense that it does not exist in the world of objects. Again, the poetic sign emerges as free of the referent, unhinged from the object in the real world. ${ }^{7}$ Thanks to this freedom it gives rise to elements of reality that are not real, existent things that do not exist, flowers we have never seen. Mallarmé notes in a letter to Cazalis of 30 October 1864: "I am inventing a language that necessarily must overflow with a very new poetics that I can define in these two words: depict not the thing, but the effect that it produces” ([15], p. 206). This effect is what I here call the performative aspect of the literary - its ability, that is, to perform and stage what does not already exist.

This performative aspect of literature conditions, as mentioned above, the all-important freedom of literature-both politically and existentially speaking. Whatever literature appears to be saying, one can always deny any realistic or referential link to the world. Therefore literature is free to criticise, to satirize and to undermine authority, without ever being finally arrested. Existentially speaking literature, because it has its inherent freedom from our common and sometimes limiting reality, can open those other aspects and dimensions of reality that move and stir us continually, and that we oftentimes yearn to relate to. In the words of Blanchot, literature can summon "what is already before 'everything', the immediate and the faraway, what is more real than all real things and what is forgotten in each thing, the link that cannot link, by which everything, the whole, is tied together" ([10], p. 47). Recalling my introductory comments, I now propose that literature, exactly because it is "referentially free”, because it can use our common language in a radically different manner than other discourses, is able to

6 This does not, of course, mean that contextual or political readings are without value. It merely reminds us to be wary of any seemingly unproblematic contextual reference, and to keep in mind the indecisiveness of literary meaning.

7 For more on this, see my article "Poetic Language and the Expression of Nothing” [14]. 
summon and echo those shades of existence that are immaterial, ineffable and supernatural. By giving the material form of poetic language to these aspects of existence, literature is spectral-it becomes a mode of in-between, sending us in direction of the real, only to suspend any such connection, sharing with us its flowers of another dimension.

\section{Literature's Hauntology}

I am sketching an understanding of literature as a language through which existence is "opened”, a language that has the force to trouble and rock the ontological demarcations by which we usually experience the world. As readers of literature, we know its potential to move and involve that which is ungraspable and indefinable. It is interesting then to note Derrida's insistence that literature itself does not subsist as an existent thing: "There is no-hardly any, ever so little-literature; that in any event there is no essence of literature, no truth of literature, no literary-being or being-literary of literature” ([16], p. 223). There is no literature. It is not an entity whose being can be defined, pinpointed or identified. That is to say that the concept of literature I am tracing cannot be reduced to the existence of books or texts. You can burn a copy of The Tempest, but the literature of the work is not destroyed. Literature does not coincide with itself.

In his book Derrida and the Future of Literature Joseph G. Kronick interestingly coins this the spectrality of literature: "The spectral quality of literature-its being a spectre-means that it is not an existent or being nor a localizable remains or archive but belongs to a future ... As a spectre, literature is neither spirit nor body and both at the same time, which makes it difficult to name” ([17], pp. 1-2). Like the spectre, literature has a shine of corporality, but this corporality, this phenomenality, is mere cloak for something that is radically absent. The being of the spectre cannot be identified with the appearance that gives it presence. It doesn't coincide with itself. But at the same time it is defined only by and through this appearing. Its presence hence becomes emblematic of its radical absence.

Literature, according to this view, is not. Its ontology is quivering. It has the materiality of language, but its essence cannot be identified with this materiality. In the above quote Kronick notes that literature belongs to the future. Blanchot also describes the sacred speaking, or the writing of the origin, as a "language of the future" ([10], p. 41). This idea of a messianic future of literature, can be traced in the works of both Derrida and Blanchot. The messianic understanding of time involves the renunciation of linear, historical time that can be measured, predicted and understood. Instead it is question of an absolute devotion to that which is to come, à venir. It involves exposing oneself to the coming of that which cannot be finally understood, which resists our categories of time and knowledge. The messianic involves a repeated opening and acceptance of the possibility of the impossible. It demands the following aporetic stance, namely to be prepared for that which one cannot be prepared for. It is not therefore concerned with actual events. As Derrida writes in The Gift of Death this is: "a logic that at bottom [...] has no need of the event of a revelation or the revelation of an event. It needs to think the possibility of such an event, but not the event itself” ([18], p. 49).

This messianic understanding frames Blanchot's retelling of the story of the beggar, who meets the Messiah at the gates of Rome. The only question the beggar can think to ask is: "When are you coming?” What is is not of interest. It is the coming, the absolute future, the can be that one turns to. According to Caputo's understanding in his book More Radical Hermeneutics "the meaning of the 
Messiah is always that, to be the horizon of hope and expectation, and we should never confuse the coming of the Messiah, his venue, with actual presence. If the Messiah ever appeared in the flesh, that would ruin everything, for what have we left to hope for and expect?” ([19], p. 178). Clearly, from the perspective of hauntology, this messianic understanding of time is interesting in that it accredits more importance to that which may exist and may come, than to all that exists in the present and has existed in the past.

This messianic understanding is linked both to literature's lack of essence and to its non-coincidence with our material reality. In the words of Blanchot: "The presence of poetry is still to come: it comes from beyond the future and does not stop coming when it is here” ([20], p. 239). Or, in The Work of Fire, "a poem is not without a date, but despite its date it is always yet to come, it speaks in a 'now' that does not answer to historical indicators" ([21], p. 112). Leslie Hill recognises this temporality in Blanchot's work of fiction L'Ârret de Mort. Without going into the complex structure of Blanchot's text, let me quote Hill's description of this temporality: "The temporality of writing here is a temporality that contests the teleology of history or historical narrative” ([22], p. 149); and events in this time belong "neither to past nor to present nor future, but rather to another time, beyond presence, between past and future, in relation to which time itself ... is continually, so to speak, beside, outside, or beyond itself” ([22], p. 150). Literature beckons us towards this dimension of time that is not, that, again, has no essence. It makes accessible a future that is to come, in the sense that it is of a different realm. It cannot be digested or folded into the linear time of our material present because it does not refer to a pre-existing reality.

This temporality is, I suggest, essential to an understanding of literature's hauntology, its lack of self-coincidence. And this hauntology in turn conditions literature's ability to somehow give (non)form to the indecisive, unfixable in-between that is also our existence. Because it is à venir literature repeatedly relates to the possibility of the hitherto impossible, the speaking of the hitherto unspeakable.

\section{Reading the Unreadable}

Considering Derrida's reflections on faith and atheism, I underscored the impossibility outlined by Derrida of saying I am a believer or I am an atheist. Because God has no being, I cannot confirm my solid state of being in relation to God. Or, put differently, God's hauntology affects my existence, introducing an element of ontological quivering also to my $I$. Having now outlined an understanding of literature as a language with no being or no essence, a language of the future, the question now is how this hauntology will affect me as a reader. What does it imply to read a language that disturbs the referential function whereby I define myself, my existence, my nationality, my meaningfulness, etc.? And how can I relate to a language that is always to come, always indicating an unknown reality to come?

Blanchot provides a starting point with the term of unreadability. In the essay "The Death of the Last Writer", he says that in "each great book there is another kind of underworld, a centre of unreadability” ([20], p. 153). Interestingly enough, these books have an underworld. Again the ontology of literature is haunted. The underworld is of course the world of shadows - the world into 
which Orpheus, a favourite of Blanchot's, descends to fetch his dead, beloved Euridyce. ${ }^{8}$ Importantly, I think, this underworld has a centre of unreadability. My understanding of the unreadable corresponds to those instances in texts when language resists our attempts at making sense of it. Language openly abandons its instrumental function of signifying, and rather enacts its different dynamics-releasing another potential. These are instances that are somehow untranslatable, and that our cognitive apparatus cannot accommodate. The centre of unreadability cannot be restated in another language or mode of language. One simply does not know what it means. We could perhaps say that these instances of the unreadable are markers of the performative force of literature whereby it is free to turn its back on reality, on common sense, on logic. Here there is simply no sense to be made, no meaning to be deciphered. And in the wake of this collapse, other shades of existence are free to emerge.

An ultimate example of unreadability is the spectral voice that testifies, in the first person, to its own death: "I die". This articulation of an impossible, unthinkable, fathom voice has of course fascinated Derrida. As he says in Demeure: "I cannot say, according to common sense, should not be able to say: I die or I am dead. If there is a place or an instance in which there is no witness for the witness or where no one is witness for the witness, it would be death” ([24], p. 46). To testify to one's own death implies that one is both dead and alive-alive enough to speak and dead enough to be speaking the truth. The moment you die you are no longer in possession of a voice that can record or testify this experience. To say "I die," is therefore, again in the words of Derrida, an "extraordinary utterance," an "incredible grammar" that is acceptable only to the literary voice.

This instance of unreadability is an articulation of the absolute aporia of ontology-namely to be dead and to possess a voice. Hence its specific interest in this context. This spectral, literary voice cannot be appropriated or understood by our analytical apparatus as it rebels against our categories of knowledge. It is as if literature, by permitting itself this utterance "I die," signals its otherness from our everyday paradigm, its ability to harbour the unheard of. This dying, haunting voice invites us as readers to give in to the movement, the speaking of the spectre. Here the hauntology of literature summons us. And, as indicated above, to interact with this voice, to have faith in it, affects how we experience our own ontology. We are permitted, strangely, through literature to relate to the haunting of our own existence, to that in us which is neither dead nor alive, neither immaterial nor concrete. Our own spectral voices, our own otherness gain in contour and move us.

This strange access to our own hauntology is intrinsically linked to a weakening of our more linear, logical reflective capabilities-a weakening I suggest can be initiated through the reading of literature. I have previously explored this aspect of the aesthetic experience as an instance of a collapse or implosion in our experience. ${ }^{9}$ This involves a suspension of our cognitive faculties, and of our experience of linear time and referential language. Through this implosion we are therefore strangely suspended, exposed to an instance that is also an eternity, sensing a radically different way of being, without language, reflection or time. Here our own ontology, our grounding in the world of verifiable

8 Of course, the myth of Orpheus is also one of spectres and of vanishing materiality. For more on Blanchot's understanding of Orpheus, see his text “Orpheus’ Gaze” in The Space of Literature ([23], pp. 171-76).

9 I have discussed this aspect of the aesthetic experience in more detail elsewhere. See Literary Silences in Pascal, Rousseau, and Beckett [3] and "The Sacrifice of Reading, Aesthetic Experience as Immanent Transcendence” [25]. 
facts and measurable entities, is smitten with the ontological quivering of the literary voice. Haunted by the unreadable, we are, I think, able to sense the spectres of our own lives.

\section{Morrison's Beloved}

So far I have sketched an understanding of poetic language as a language that is free to suspend its referential function and hence its link to our material world. This is the all-important freedom of literature that in turn allows it to convey those aspects of our existence that have no ontological substance and that our logical, everyday use of language fails to convey. Literature, because it can give voice to the unreadable, to the impossible, is the language through which it is possible to gain a renewed proximity to all those layers of our lives that are not, but that nonetheless haunt us continuously. Given this context I would like to turn now to Toni Morrison's novel Beloved and its various spectres. $^{10}$

In an interview Morrison describes how Afro-Americans have had to repress the atrocities of their past in order to make a new life for themselves: "I think Afro-Americans in rushing away from slavery, which was important to do - it meant rushing out of bondage to freedom—also rushed away from the slaves because it was painful to dwell there, and they may have abandoned some responsibilities in so doing. It was a double edged sword, if you understand me” ([30], p. 33). The necessary repression of the past, also grants it an unconscious haunting power. The book deals with this difficulty - how to remember what the present cannot bear? How to live on when every moment is caught up in the unspeakable shame, pain and inhumanity of the past? "There is a necessity for remembering the horror, but of course there's a necessity for remembering it in a manner which it can be digested, a manner in which the memory is not destructive” (ibid.). The challenge faced by the literary imagination is to remember, to recollect the past in manner in which it becomes bearable.

History books can give us the facts, but this is only part of the task of memory. In the essay "The Site of Memory”, Morrison distinguishes not between fact and fiction, but between fact and truth: "Because facts can exist without human intelligence, but truth cannot" ([31], p. 113). In other words, history books might give us facts, but not the truth. The truth of history and of its traumatic happenings lies, according to Morrison, in the inner lives of the individuals. And to access these inner lives requires the literary act of imagination: "Only the act of imagination can help” ([31], p. 111). Imagination is the faculty by which we depart from the confines of the real, and strive towards the in-between of hauntology. Here we are not burdened by the facts of the past or by the materiality of the present, but rather free to roam a different landscape, a landscape that invites and permits our emotional partaking in an immaterial and lost present moment. We are here, yet we are not here.

10 Needless to say, the thematics of hauting in Morrison's novel have been discussed widely and in-depth elsewhere (see for example Avery Gordon, Ghostly Matters: Haunting and the Sociological Imagination, pp. 64-137 [26], Jeffrey Andrew Weinstock, “Ten Minutes for Seven Letters” [27], Deborah Horovitz, "Nameless Ghosts, Posession and Dispossesion in Beloved” [28] and Caroline Rody, “Toni Morrison’s Beloved, History, Rememory' and a 'Clamor for a Kiss'” [29]. It is not my intention to contribute specifically to this sholarship, but rather to show hos Morrison's novel enriches my understanding of the priceless value of literature when it comes to dealing with the "in-between", the quivering ontololgy that continously haunts us. 
The daunting challenge of the literary imagination in Beloved is to somehow give voice to those traumatic and extreme specters of emotions that are too easily betrayed by the language of facts and of history books. A referential mention of shame, of despair, of horror misses the mark. Hence Morrison's work with the literary language strives to implode the limits of everyday language in order to give us access to the inner experiences of these emotional nuances-nuances that even those who experience them first hand have no words for. It is therefore Morrison's genius to invoke a ghost, a living dead - the absolute aporia, an impossibility that in itself implodes our categories of what can and cannot be. It is this voice, this poetic speaking, that strives to make the unbearable past bearable.

There is one passage of the novel I shall dwell on, namely the monologue of Beloved. Beloved is the name of the silent and mysterious woman who turns up at to the house of the main character Sethe and her daughter Denver. Sethe's house has been haunted by the sad and angry ghost of her baby daughter, who Sethe herself killed in a desperate and unreal moment of overwhelming fear that her daughter would face a life in slavery. On her headstone is engraved the epitaph Beloved. As readers we understand early on that the woman is the baby ghost in a different form-more material, more enduring, more demanding. She has come back from a beyond, it seems, to claim Sethe for herself. She avidly demands the love and recognition from her mother, as she seeks some form of understanding or reconciliation with her history and her death. She is, in other words, a haunted ghost, whose presence slowly but surely devours Sethe. Only through the collected effort of the community is she exorcised, thereby permitting a new beginning if not for Sethe, then for Sethe's other daughter Denver. But Beloved is not only Sethe's personal spectre. She has a double character, as she is also the ghost of an unnamed victim of the transport of slaves from Africa-the Middle Passage. A gruesome holocaust of which the number of victims is not precisely known, but according to Morrison, sixty million or more perished (hence her dedication at the start of Beloved "Sixty Million and more"). It is from these unspeakable horrors that Beloved returns to give some kind of impossible testimony.

In the character of Beloved, then, the specific story of Sethe's trauma meets the horror of the general destiny of these sixty million and more. Through this work of literary imagination, the facts of history emerge in a radically different manner, striving towards a different truth. Central here are the two sections towards the end of the novel, where Morrison lends the first person "I" to Beloved, the ghost. Both sections start with the sentence "I am Beloved and she is mine". "She” refers, it seems, both to Sethe and to the unnamed mother of the Middle Passage ghost. ${ }^{11}$ This appears as a clear instance of the unreadability mentioned above, where a voice speaks from the impossible stance of its own death, I am dead. The center of unreadability that Blanchot defines as the underworld of each great work, here spans almost ten pages. And through this feat of imagination, I suggest that Morrison, in a crystalised poetic form, succeeds in giving literary form to that haunting which is the African-American destiny.

A closer look at these sections reveal a style that is highly fragmentary, displaying a radical breakdown of meaning, syntax and referentiality.

11 D. Horovitz, in the article "Nameless Ghosts, Posession and Dispossesion in Beloved” [28], convincingly reads Beloved from the ship as the the ghost of Sethe's own mother. 
I would help her but the clouds are in the way how can I say things that are pictures I am not separate from her there is no place where I stop her face is my own and I want to be there in the place where her face is and to be looking at it too a hot thing ([32], p. 248).

Or later on:

I am standing in the rain falling the others are taken I am not taken I am falling like the rain is I watch him eat inside I am crouching to keep from falling with the rain I am going to be in pieces he hurts where I sleep he puts his finger there I drop the food and break into pieces she took my face away there is no one to want me to say me my name ([32], p. 251).

These lines give rise to an experience of acute aloneness and abandonment, and a desire to be reunited with the other, with the mother. Yet none of these emotions are named, no clear meaning can be summarized. Rather it is as if meaning were suspended, put on hold, made fluid, "All of it is now it is always now" ([32], p. 48). The linearity that conditions meaningful syntax is put on hold. We are presented with images that challenge our intuitive understanding, "she empties out her eyes", "the sun closes my eyes", "I am the laughter", "she goes in the water with my face”, etc. These are pages through which we repeatedly are offered versions of Mallarmé's flowers-absent from any bouquet, unreal, other, yet strangely familiar. The reality evoked is the immediate, emotional and sensory experience of this floating "I", this spectral voice. And only through this speaking, this imploding poetic language, can we perhaps sense the pain of this unarticulated horror, this pain that is spectral because we cannot relate to it within the limitations of our everyday paradigm.

There are many readings that show how these passages can be made more intelligible with reference to the transport of slaves from Africa to America - the Middle Passage. ${ }^{12}$ But, in this context, what matters more is that this is a language that openly problematizes its relation to any historical event, because it seeks to challenge the representation of history. It remains that we are reading a language that is fraying at the edges, undoing itself. It is the language of a ghost, and it brings witness to a range of experiences that in their horror are spectral in the sense of unbearable, unimaginable from the point of everyday, referential language. The supernatural is part of history, not necessarily in the form of ghosts, but in the sense of that which, in its horror, challenges the confines of what is understood as "natural”. By invoking the ghost, and giving it a first person monologue, Morrison rips open the veil of reality and reveals all those unspeakable shades of experience that implode our cognititve mastery, but that are nonetheless real. The language of trauma emerges as particular to literature, and it is the mark of literariness that it can to such an extent divorce itself from meaning, and yet be so deeply meaningful.

\section{Conclusions}

What Morrison's text demands from its readers is that they have faith in the ghosts of literature. And to have this faith is to be smitten with the quivering ontology of that in which we believe. In Beloved this spectrailty is more tangible as one of the main characters is a ghost. However, and here I

12 See for example Deborah Horovitz' article "Nameless Ghosts, Posession and Dispossesion in Beloved” [28], Sally Keenan, “Four Hundred Years of Silence’: Myth, History and Motherhood in Toni Morrison’s Beloved” [33] or Elizabeth B. House “Toni Morrison’s Ghost: The Beloved Who is not Beloved” [34]. 
recall Blanchot, every great text has its center of unreadability, its spectrality. Literature is the release of this middle zone, this in-between, that haunts us all. So to read literature is to be exposed to the hauntology of the text, and thereby to one's own spectrality. In what sense am I? What is it to exist? Where do I end and does the other start? How does the death of others, and my own death, haunt me? How can I live with the knowledge of all that I can never know?

In Writings of the Disaster, Blanchot writes, "Reading is anguish, and this is because any text, however important, amusing or interesting it may be (and the more engaging it seems to be), is empty - at bottom it does not exist; you have to cross an abyss, and if you do not jump, you do not comprehend” ([35], p. 10, my italics). The literary text does not exist; at least not within our traditional ontological understanding. In order to read therefore, we must cross an abyss, jump into a realm that I have here designated as one of hauntology. This involves abandoning our ontological paradigm that only grants existence to that which is materially present and conceptually definable. This of course stirs our anxiety. But to endure this anxiety is to gain access to our own hauntology, to our own death, as it haunts our lives. Literature invites us into this realm; it performs it through its breakage of words, its implosion and suspension of meaning. And as readers we are beckoned to participate, to cross lines, to jump and thereby experience the stirrings of that which lies in between-in between life and death, spirit and matter, time and eternity.

\section{Conflict of Interest}

The author declares no conflict of interest.

\section{References}

1. Colin Davis. Haunted Subjects, Deconstruction, Psychoanalysis and the Return of the Dead. London: Palgrave Macmillan, 2007.

2. Jodey Castricano. Cryptomimesis, The Gothic and Jacques Derrida's Ghost Writing. Montreal and Kingston: McGill-Queen’s Press, 2001.

3. Elisabeth M. Loevlie. Literary Silences in Pascal, Rousseau, and Beckett. Oxford Univ. Press, 2003.

4. Jacques Derrida. “Circumfession: Fifty-nine Periods and Periphrases.” In Jacques Derrida. By Geoffrey Bennington and Jacques Derrida. Chicago: Chicago Univ. Press, 1993.

5. Yvonne Sherwood, and Kevin Hart, eds. Derrida and Religion, Other Testaments. London and New York: Routledge, 2005.

6. Mother Teresa. Mother Teresa: Come Be My Light. Edited by Brian Kolodiejchuk. New York: Doubleday, 2007.

7. Blaise Pascal. Pensées. Oxford: Oxford Univ. Press, 1999.

8. Jacques Derrida. Writing and Difference. London and New York: Routledge, 1978.

9. John D. Caputo. “Introduction: Who Comes After the God of Metaphysics.” The Religious. Edited by John D. Caputo. Oxford: Blackwell Publishers, 2002, 1-28.

10. Maurice Blanchot. "The Beast of Lascaux.” In A Voice from Elsewhere. Albany: State Univ. of New York Press, 2007. 
11. Jacques Derrida. On the Name. Edited by Thomas Dutoit. Stanford: Stanford Univ. Press, 1995.

12. Jacques Derrida. "Literature in Secret, An Impossible Filiation.” In The Gift of Death. Chicago: Chicago Univ. Press, 2008.

13. Stéphane Mallarmé. “Crisis in Poetry.” In Selected Poetry and Prose. Edited and translated by Mary Ann Caws. New York: New Direction, 1982.

14. Elisabeth M. Loevlie. "Poetic Language and the Expression of Nothing. Towards a Kenotic Weakening of Referential Language.” Angelaki: Journal of the Theoretical Humanities 17 (2012): 85-96.

15. Stéphane Mallarmé. Correspondance. Lettres sur la poésie. Paris: Gallimard, 1995.

16. Jacques Derrida. Dissemination. Chicago: Chigaco Univ. Press, 1981.

17. Joseph G. Kronick. Derrida and the Future of Literature. Albany: SUNY, 1999.

18. Jacques Derrida. The Gift of Death. Chicago: Chicago Univ. Press, 1995.

19. John D. Caputo. More Radical hermeneutics, On Not Knowing Who We Are. Bloomington and Indianapolis: Indiana Univ. Press, 2000.

20. Maurice Blanchot. The Book to Come. Stanford: Stanford Univ. Press, 2003.

21. Maurice Blanchot. The Work of Fire. Stanford: Stanford Univ. Press, 1995.

22. Leslie Hill. Blanchot: Extreme Contemporary. London and New York: Routledge, 1997.

23. Maurice Blanchot. The Space of Literature. Nebraska: Univ. of Nebraska Press, 1989.

24. Jacques Derrida. Demeure, Fiction and Testimony. Translated by Elizabeth Rottenberg. Stanford: Stanford University Press, 2000.

25. Elisabeth M. Loevlie. "The Sacrifice of Reading, Aesthetic Experience as Immanent Transcendence.” In Transfigurations, Nordic Journal of Religion and the Arts 2010/2011. Copenhagen: Museum Tusculanum Press, 2011.

26. Avery Gordon. Ghostly Matters: Haunting and the Sociological Imagination. Minneapolis: Univ. of Minnesota Press, 2008.

27. Jeffrey Andrew Weinstock. “Ten Minutes for Seven Letters.” In Toni Morrison's Beloved, Bloom's Modern Critical Guides. Edited by Harold Bloom. New York: Infobase Publishing 2009, 73-92.

28. Deborah Horovitz. "Nameless Ghosts, Posession and Dispossesion in Beloved." Studies in American Fiction 17 (1989): 157-68.

29. Caroline Rody. “Toni Morrison's Beloved, History, 'Rememory' and a 'Clamor for a Kiss'”. American Literary History 7 (1995): 92-119.

30. Carl Plasa, ed. Toni Morrison Beloved, Columbia Critical Guides. New York: Columbia Univ. Press, 1998.

31. Toni Morrison. "The Site of Memory." In Inventing the Truth, The Art and Craft of Memoir. Edited by William Zinser. Boston: Houghton Mifflin Company, 1987, 103-24.

32. Toni Morrison. Beloved. London: Vintage Books, 2005.

33. Sally Keenan. “'Four Hundred Years of Silence’: Myth, History and Motherhood in Toni Morrison's Beloved.” In Recasting the World: Writing after Colonialism. Edited by Jonathan White. Baltimore: John Hopkins Univ. Press, 1993, 45-81. 
34. Elizabeth B. House. "Toni Morrison's Ghost: The Beloved Who is not Beloved.” Studies in American Fiction 18 (1990): 17-26.

35. Maurice Blanchot. Writings of the Disaster. Nebraska: Univ. of Nebraska Press, 1995.

(C) 2013 by the author; licensee MDPI, Basel, Switzerland. This article is an open access article distributed under the terms and conditions of the Creative Commons Attribution license (http://creativecommons.org/licenses/by/3.0/). 